\title{
Review and development of statistical models for calculating the economic base of wine production
}

\author{
Milana Shevchenko ${ }^{1}$, Natella Kosenko, \\ ${ }^{1}$ Private educational institution of higher education «Moscow University named after S.Y. Witte», 78, \\ Nefedova, 344018, Rostov-on-Don, Russia \\ ${ }^{2}$ Don State Technical University, 1, Gagarina sq., 344003, Rostov-on-Don, Russia
}

\begin{abstract}
In the article the economic basis of wine production in the regions is examined and evaluated; known methods of identifying alternatives to the development of the wine-vineyard market of regions that simultaneously produce grapes and wines for sale in the country and for export are analyzed. Emphasis is placed on the production of wines from imported wine materials.
\end{abstract}

\section{Introduction}

One of the first static models for calculating the economic base is called the regional income model formulated by Homer Hoyt. It was subsequently reviewed by H. Richardson, who N. Glickman refers to in his approach to this model analysis [1].

The concept of the economic framework calculation model assumes that the local (regional) economy is divided according to markets for goods into two sectors: the basic sector which focuses on export and the tertiary sector with the focus on consumption within the region. Both sectors generate income (revenue).

H. Hoyt, H. Richardson and N. Glickman represented the statistical model for the iregion as

$$
Y_{i}=\left(E_{i}-M_{i}\right)+X_{i},
$$

where $Y_{i}$ stands for total income in the i-region;

$\mathrm{E}_{\mathrm{i}}$ - own expenditures (More precisely, own income) (including consumption, investment and local government expenditures) in the i-region;

$\mathrm{M}_{\mathrm{i}}$ - imports into the i-region;

$\mathrm{X}_{\mathrm{i}}$ - exports from the $\mathrm{i}$ region.

\footnotetext{
*Corresponding author:natella_05@bk.ru
} 


\section{Methods and materials}

The authors consider a dynamic model that takes into account the annual variation in own wine production costs and the purchase of imported wines. Consumption, local expenditures, imports and exports vary from one year to another, have an impact on the region's total income. The impact can be calculated via coefficients of variation according to the following formulas (2) and (3):

$$
\begin{gathered}
\mathrm{E}_{\mathrm{i}}=\mathrm{e}_{\mathrm{i}} \mathrm{Y}_{\mathrm{i}}, \\
\mathrm{M}_{\mathrm{i}}=\mathrm{m}_{\mathrm{i}} \mathrm{Y}_{\mathrm{i}}, \\
\mathrm{X}_{\mathrm{i}}=\overline{\mathrm{X}}_{\mathrm{i}} .
\end{gathered}
$$

The line above indicates that the variable is exogenous (externally induced) in this model.

By placing (2), (3) and (4) to the main equation (1), we get

$$
Y_{i}=e_{i} Y_{i}-m_{i} Y_{i}+\bar{X}_{i} \text {. }
$$

The $e_{i}$ and $m_{i}$ coefficients are not trivial coefficients as they vary for different regions, markets, or goods from year to year.

The calculation of these coefficients, as well as the evolution coefficients of many other values used in the model of economic base of the region, is part of the scientific study [2]. Plausible official statistics are used to calculate the coefficients.

From formula (5) we get

$$
Y_{i}=\frac{\bar{X}_{i}}{1-e_{i}+m_{i}} .
$$

Thus, regional income is determined by the value of exports $\bar{X}_{i}$ (externally induced) and the marginal propensity to spend within the region $\left(e_{i}-m_{i}\right)$. By further differentiating the formula (6) from exports, we get a basic multiplier - a coefficient showing the effect of one economic indicator on another, in this case exports on regional income:

$$
\mathrm{k}=\frac{\mathrm{dY} \mathrm{Y}_{\mathrm{i}}}{\mathrm{d} \overline{\mathrm{X}}_{\mathrm{i}}}=\frac{1}{1-\mathrm{e}_{\mathrm{i}}+\mathrm{m}_{\mathrm{i}}}=\frac{\mathrm{Y}_{\mathrm{i}}}{\overline{\mathrm{X}}_{\mathrm{i}}}
$$

Equation (7) shows that the average and limit values of these relationships $\frac{Y_{i}}{\bar{X}_{i}}=\frac{d Y_{i}}{d \bar{X}_{i}}$ are equal. In fact, the resultant formula (7) describes a simple case of cross-regional trade multiplier [3].

Let us cast away the premise that exports are the only source of economic growth and replace it with a model that takes advantage of exogenously obtained levels of investment, government spending and consumption.

The value of exports-imports is now determined through interaction with the activities of $\mathbf{n}$ other regions. Then the equation of regional income (1) is transformed into

$$
\mathrm{Y}_{\mathrm{i}}=\mathrm{C}_{\mathrm{i}}+\mathrm{I}_{\mathrm{i}}+\mathrm{G}_{\mathrm{i}}+\mathrm{X}_{\mathrm{i}}-\mathrm{M}_{\mathrm{i}}
$$

where $\mathrm{C}_{\mathrm{i}}$ - consumption in the i-region,

$\mathrm{I}_{\mathrm{i}}$ - investments in the i-region,

$\mathrm{G}_{\mathrm{i}}$ - government expenditures in the i-region,

$\mathrm{X}_{\mathrm{i}}$ - exports from the i-region,

$\mathrm{M}_{\mathrm{i}}$ - imports into the i-region. 
Consumption depends linearly on the well-being of the region's residents, on the income generated by any means. This dependence takes the form of:

$$
\begin{gathered}
\mathrm{C}_{\mathrm{i}}=\mathrm{a}_{\mathrm{i}}+\mathrm{b}_{\mathrm{i}} \mathrm{Y}_{\mathrm{i}}^{\mathrm{d}}, \\
\mathrm{I}_{\mathrm{i}}=\overline{\mathrm{I}}_{\mathrm{i}}, \\
\mathrm{G}_{\mathrm{i}}=\overline{\mathrm{G}}_{\mathrm{i}}, \\
\mathrm{X}_{\mathrm{i}}=\sum_{\mathrm{i}=1} \mathrm{M}_{\mathrm{ij}}=\sum_{\mathrm{i}=1} \mathrm{~m}_{\mathrm{ij}} \mathrm{Y}_{\mathrm{j}}^{\mathrm{d}}, \\
\mathrm{M}_{\mathrm{i}}=\sum_{\mathrm{i}=1} \mathrm{~m}_{\mathrm{ij}} \mathrm{Y}_{\mathrm{i}}^{\mathrm{d}}, \\
\mathrm{T}_{\mathrm{i}}=\mathrm{t}_{\mathrm{i}} \mathrm{Y}_{\mathrm{i}} .
\end{gathered}
$$

$\mathrm{Y}^{\mathrm{d}}$ represents free income and $\mathrm{t}_{\mathrm{i}}-\operatorname{tax}$ limit. If the autonomous costs are recorded as

$$
\mathrm{A}_{\mathrm{i}}=\mathrm{a}_{\mathrm{i}}+\overline{\mathrm{I}}_{\mathrm{i}}+\overline{\mathrm{G}}_{\mathrm{i}}
$$

and the expression is substituted in (8), we get

$$
Y_{i}=\frac{A_{i}+\sum_{j=1} m_{i j} Y_{j}\left(1-t_{j}\right)}{1-\left(b_{i}-\sum_{j=1} m_{i j}\right)\left(1-t_{i}\right)}
$$

Hence the multiplier is

$$
\mathrm{k}=\frac{1}{1-\left(\mathrm{b}_{\mathrm{i}}-\sum_{\mathrm{j}=1} \mathrm{~m}_{\mathrm{ij}}\right)\left(1-\mathrm{t}_{\mathrm{i}}\right)} .
$$

In such a cross-regional trade model the value of regional income can vary as a result of changes in four main factors:

- exports as in the economic base model (1);

- any of the components of the model (15), mainly investments and government expenditures;

- income in other regions with influence on exports from the i-region;

- one of the model parameters (for example, $b_{i}, t_{i}$ ).

\section{Results and discussing}

The resulting model of cross-regional trade is more capacious than the economic base model. As a result of the census, it can be implemented using the methods we have already developed for determining the specific values of the coefficients used in the calculations.

The identification of export and service components and their attribution to agricultural producers who sell to local (intermediary) producers to a firm that then exports or exports it poses a challenge to be faced. Two useful methods of addressing this problem can be identified in the papers on the regional economy [4].

The first of these approaches assumes the nature of the market for each industry. The second approach used to distinguish sectors is the use of a localization factor, or a specialization ratio. The specialization ratio is defined as follows:

$$
L Q=\frac{\frac{E_{i j}}{E_{i t}}}{\frac{E_{n j}}{E_{n t}}}=\frac{\frac{E_{i j}}{E_{n j}}}{\frac{E_{i t}}{E_{n t}}},
$$


where LQ is the specialization ratio;

$\mathrm{E}_{\mathrm{ij}}$ - volume of employment in the j-industry (winemaking) in the i-region;

$\mathrm{E}_{\mathrm{it}}$ - general employment in the i-region;

$E_{n j}$ - nationwide volume of employment in the j-industry (winemaking) for the country in general;

$\mathrm{E}_{\mathrm{nt}}$ - overall employment in the country.

The indicator should reflect the relative specialization of the region. If in the region the share of conventional employment in the industry is higher than in the country, i.e. the localization ratio is greater than one, it is assumed that there is in fact an excess and that it works for exports from the region. For example, if

$$
E_{i j}=10, E_{i t}=100, E_{n j}=100, E_{n t}=2000,
$$

then the specialization ratio equals 2 . Five employees are related to the export part of $j$ industry and other five work for the local market. The localization ratio is calculated for each industry in the i-region, and result in a ratio between the base and tertiary sectors. Unfortunately, statistics on the number of winemaking workers in the regions are not recorded.

The described framework consideres both direct and indirect exports. Glass indystry representation stems from the grape processing in Krasnodar region. Although glass producers sell their products to local wine processors, the final product of the manufacturing chain is exported. It is therefore reasonable to include manufacturers of glassware in the export category (indirect). The specialization ratio is a good measure of export-related activities since it determines the degree of concentration of firms in a given industry. However, there are a number of shortcomings in the approach considered:

firstly, the relationship between production and consumption is implicitly taken as the same across country;

secondly, the existence of international foreign trade is not taken into account;

thirdly, the reciprocal transit of goods is ignored with the specialization coefficient usage, since all local demand is assumed to be satisfied by local production. This leads to underestimation of the export base size and overestimation of the multiplier.

Edward Louis Ullman and Michael Dacey [1] have developed a method of the minimum requirements for goods. The methodology can be criticized in the same way as the specialization rate, the shortcomings of which it seeks to correct:

firstly, the same assumptions about the same ratio of production to consumption are implicitly used for all regions;

secondly, since the minimum needs approach assumes that the region with the lowest share of the industry meets its domestic needs for its products, this is true for any other region. Thus, each region should export, but none can import, excluding imports of intermediate products (for example, alcohol), which are then re-exported through the final product;

thirdly, using this method, with greater detail, the minimum share of each industry will be approaching zero, which inevitably leads to an absurd conclusion that regions do not have domestic needs and that all products are exported.

By criticizing Ulman-Dacey's approach, one can argue that the method of maximizing needs would be more useful. In this approach the entities with the maximum share of any industry satisfy their domestic needs, while all others import the same product. Such reasoning leads to the conclusion that the subjects do not export products at all. The result is same absurd as the conclusion that there are no imports.

Evaluation of measurement errors associated with the application of both the specialization ratio and the method of minimum needs are estimated in the work of D. 
Greytak [1], who indicated that in both cases the export estimates differ significantly from the actual values.

By examining the accuracy of estimates with the aid of G. Teil's inequation [1], we find that the «systematic error» is quite large. The minimum requirements method, according to Greytak, is more precise than the specialization ratio method, but neither is satisfactory. [5] Regression analysis is a simplified method used to distinguish the economic base. This method was first used by Hildebrand and Mace [6] and then by a number of other authors.

The last approach under consideration for determining the economic base includes an expensive but more precise method - a survey of each farm enterprise to estimate the boundaries of the basic sector. [7-12] These enterprises are asked to determine the proportion of sales of their products outside the region. The basic sector is distinguished by sample estimates. In addition to the high cost of any primary data collection, a problem of accuracy remains a challenge, as often entrepreneurs have only a vague idea of the geographical distribution of their clientele. In addition, the researcher has to allocate indirect exports, i.e. producers who sell to other local firms supplying products outside the region. Questionnaire methods are often combined with the specialization factor to address this problem.

The formula (1) we have reformed for the wine market is as follows:

$$
\mathrm{Y}_{\mathrm{i}}=\mathrm{E}_{\mathrm{i}}^{1}+\mathrm{E}_{\mathrm{i}}^{2}+\mathrm{Z}_{\mathrm{i}}-\mathrm{M}_{\mathrm{i}}-\mathrm{B}_{\mathrm{i}}+\mathrm{X}_{\mathrm{i}}+\mathrm{W}_{\mathrm{i}}
$$

where: $\mathrm{Y}_{\mathrm{i}}$ is the total income in the i-region from production of grape wines, champagne and sparkling wines in the controlled period;

$\mathrm{P}_{\mathrm{i}}$ is the production of winemaking products from grapes grown in the territory of $\mathrm{i}$ subject;

$\mathrm{P}_{\mathrm{i}}{ }^{1}-$ production of fortified wines with strength of up to 20 per cent and grape table dry, semi-dry, semi-sweet wines with strength of up to 14 per cent of alcohol and up to 8 per cent of sugar, liter;

$\mathrm{P}_{\mathrm{i}}^{2}$ - production of champagne and domestic sparkling wines, liter;

$\mathrm{E}_{\mathrm{i}}{ }^{1}$ - the number of grape wines consumed by the population in the i-region as a result of retail sales;

$\mathrm{E}_{\mathrm{i}}{ }^{11}$ - quantity of grape fortified wines with strength up to 20 per cent alcohol, liter, in retail sale;

$\mathrm{E}_{\mathrm{i}}^{12}$ - grape table dry, semi-dry, semi-sweet wines with strength of up to 14 per cent of alcohol and up to 8 per cent of sugar, liter, in retail sale;

$\mathrm{E}_{\mathrm{i}}^{2}-$ quantity of consumed champagne and domestic sparkling wines region in the $\mathrm{i}$ region in retail sale;

$\mathrm{Z}_{\mathrm{i}}$ - investments and expenditures of local government in the i-region;

$\mathrm{M}_{\mathrm{i}}$ - importation of winemaking products to the i-region;

$\mathrm{V}_{\mathrm{i}}$ - income from sales of wines in the territory of the subject;

$\mathrm{B}_{\mathrm{i}}-$ the cost of importing winemaking products from other domestic regions;

$\mathrm{B}_{\mathrm{i}}{ }^{1}$ - import of grape products from other regions;

$\mathrm{B}_{\mathrm{i}}{ }^{11}$ - import of fortified wines with strength up to 20 per cent alcohol, liter, from other domestic regions;

$\mathrm{B}_{\mathrm{i}}{ }^{12}$ - import grape table dry, semi-dry, semi-sweet wines with strength of up to 14 per cent of alcohol and up to 8 per cent of sugar, liter, from other regions of Russia;

$\mathrm{B}_{\mathrm{i}}{ }^{2}$ - import of champagne and domestic sparkling wines from other domestic regions;

$\mathrm{X}_{\mathrm{i}}$ - exports from the i-region;

$\mathrm{W}_{\mathrm{i}}$ - export of winemaking products to other domestic regions:

$\mathrm{W}_{\mathrm{i}}{ }^{11}$ - export of grape fortified wines with strength up to 20 per cent alcohol, liter, to other domestic regions; 
$\mathrm{W}_{\mathrm{i}}{ }^{12}$ - export grape table dry, semi-dry, semi-sweet wines with strength of up to 14 per cent of alcohol and up to 8 per cent of sugar, liter, to other regions of Russia;

$\mathrm{W}_{\mathrm{i}}^{2}$ - export of champagne and domestic sparkling wines to other domestic regions;

$\mathrm{C}_{\mathrm{i}}^{\text {str. }}$ - price of fortified wines with strength up to 20 per cent alcohol, liter;

$\mathrm{C}_{\mathrm{i}}^{\mathrm{drIx}}$ - price of grape table dry, semi-dry, semi-sweet wines with strength of up to 14 per cent of alcohol and up to 8 per cent of sugar, liter;

$\mathrm{C}_{\mathrm{i}}^{\text {SparkIc. }}$ - price of champagne and domestic sparkling wines.

The production of wineries varies from one year to another due to changes in natural conditions. In order to correct this deficiency in further calculations and to maintain the necessary accuracy, it is proposed to calculate the average growth factors for each of the participating indicators.

Let's calculate the average growth rates for the members of the Southern Federal District, whose economy is connected with the production of winemaking products, as follows:

$\mathrm{g}_{\mathrm{i}}{ }^{1}$ - the production of grape wines;

$\mathrm{g}_{\mathrm{i}}{ }^{2}$ - the production of champagne and sparkling wines;

$\mathrm{d}_{\mathrm{i}}{ }^{1}$ - the sutface area allocated for vineyards;

$\mathrm{d}_{\mathrm{i}}^{2}$ - total harvest of grapes;

$\mathrm{d}_{\mathrm{i}}^{3}$ - yield of grapes;

$\mathrm{e}_{\mathrm{i}}{ }^{1}$ - the number of grape wines sold on domestic markets of the same subject;

- ei11 - the number of sold grape fortified wines with strength up to 20 per cent alcohol;

- ei12 - the number of sold grape table dry, semi-dry, semi-sweet wines with strength of up to 14 per cent of alcohol and up to 8 per cent of sugar;

- ei21 - the price of sold grape fortified wines with strength up to 20 per cent alcohol;

- ei22 - the price of sold grape table dry, semi-dry, semi-sweet wines with strength of up

to 14 per cent of alcohol and up to 8 per cent of sugar;

- $\quad$ si3 - prices for imported champagne and sparkling wines;

- $\quad$ sil - the number of champagne and sparkling wines sold;

- $\quad$ si 2 - the price of champagne and sparkling wines sold;

pi - targeted investments in the agricultural sector for restoration of vineyards by the entities of the Southern Federal District;

$\mathrm{m}_{\mathrm{i}}-$ imports of wine stock in value terms;

$\mathrm{n}_{\mathrm{i}}-$ importation of wines from other subjects of domestic regions;

$\mathrm{q}_{\mathrm{i}}$ - wine exports;

$\mathrm{r}_{\mathrm{i}}$ - exportation of wines to other domestic regions.

In further calculations we will use formula (12), bearing in mind the fact that the economic base of wine production is not static and depends on many factors. In each element of formula (12) the limits of its admissible variation will be considered. To achieve this goal, the growth coefficients (changes in time) of each parameter are determined, in particular during the last $4-5$ years. Under these conditions, formula (20) is converted into the following symbolic form (21):

$$
\mathrm{Y}_{\mathrm{i}}=\mathrm{V}_{\mathrm{i}}-\mathrm{n}_{\mathrm{i}} \cdot \mathrm{B}_{\mathrm{i}}+\mathrm{r}_{\mathrm{i}} \cdot \mathrm{W}_{\mathrm{i}}+\mathrm{p}_{\mathrm{i}} \cdot \mathrm{Z}_{\mathrm{i}}+\mathrm{q}_{\mathrm{i}} \cdot \mathrm{X}_{\mathrm{i}}-\mathrm{m}_{\mathrm{i}} \cdot \mathrm{M}_{\mathrm{i}}
$$

Retail income from grape wines is determined from the following formulas:

$$
\begin{aligned}
& \mathrm{V}_{\mathrm{i}}=\mathrm{e}_{\mathrm{i}}{ }^{1} \cdot \mathrm{e}_{\mathrm{i}}{ }^{11} \cdot \mathrm{E}_{\mathrm{i}}{ }^{11} \cdot \mathrm{C}_{\mathrm{i}}^{\text {str. }}+\mathrm{e}_{\mathrm{i}}{ }^{1} \cdot \mathrm{e}_{\mathrm{i}}{ }^{12} \cdot \mathrm{E}_{\mathrm{i}}{ }^{12} \cdot \mathrm{C}_{\mathrm{i}}{ }^{\text {drIx }}+\mathrm{s}_{\mathrm{i}}{ }^{1} \cdot \mathrm{s}_{\mathrm{i}}{ }^{2} \mathrm{E}_{\mathrm{i}}{ }^{2} \cdot \mathrm{C}_{\mathrm{i}}{ }^{\text {SparkIc. }} \\
& \mathrm{E}_{\mathrm{i}}^{1}=\mathrm{E}_{\mathrm{i}}^{11}+\mathrm{E}_{\mathrm{i}}^{12}
\end{aligned}
$$

Value of wine-vineyard goods produced from grapes grown on the territory of the same subject: 


$$
\mathrm{P}_{\mathrm{i}}=\mathrm{g}_{\mathrm{i}}^{1} \mathrm{e}_{\mathrm{i}}^{21} \mathrm{P}_{\mathrm{i}}^{1}\left(\mathrm{C}_{\mathrm{i}}^{\mathrm{str}}+\mathrm{C}_{\mathrm{i}}^{\mathrm{drIx}}\right) / 2+\mathrm{g}_{\mathrm{i}}^{2} \mathrm{~s}_{\mathrm{i}}^{2} \mathrm{P}_{\mathrm{i}}^{2} \mathrm{C}_{\mathrm{i}}^{\text {SparkIc. }}
$$

$\left(C_{i}^{\text {str }}+C_{i}^{\text {drIx }}\right) / 2$ - average value of fortified wines on the territory of a given subject.

Price of importation of wine-vineyard goods from other domestic regions:

$$
\begin{gathered}
\mathrm{B}_{\mathrm{i}}=\mathrm{e}_{\mathrm{i}}^{11} \cdot \mathrm{n}_{\mathrm{i}}^{11} \cdot \mathrm{B}_{\mathrm{i}}{ }^{11} \cdot \mathrm{C}_{\mathrm{i}}^{\text {str. }}+\mathrm{e}_{\mathrm{i}}{ }^{12} \cdot \mathrm{n}_{\mathrm{i}}{ }^{12} \cdot \mathrm{B}_{\mathrm{i}}{ }^{12} \cdot \mathrm{C}_{\mathrm{i}}{ }^{\mathrm{drIx}}+\mathrm{n}_{\mathrm{i}}{ }^{2} \cdot \mathrm{s}_{\mathrm{i}}{ }^{2} \cdot \mathrm{B}_{\mathrm{i}}{ }^{2} \cdot \mathrm{C}_{\mathrm{i}}^{\text {Sparklc }} \\
\mathrm{B}_{\mathrm{i}}{ }^{1}=\mathrm{B}_{\mathrm{i}}{ }^{11}+\mathrm{B}_{\mathrm{i}}{ }^{12}
\end{gathered}
$$

Price of wine-vineyard goods exported to markets of other domestic entities:

$$
\begin{aligned}
& \mathrm{W}_{\mathrm{i}}=\mathrm{r}_{\mathrm{i}} \cdot\left[\mathrm{e}_{\mathrm{i}}^{11} \cdot \mathrm{W}_{\mathrm{i}}^{11} \cdot \mathrm{C}_{\mathrm{i}}^{\text {str. }}+\mathrm{e}_{\mathrm{i}}^{12} \cdot \mathrm{W}_{\mathrm{i}}{ }^{12} \cdot \mathrm{C}_{\mathrm{i}}^{\mathrm{drIx}}\right]+\mathrm{s}_{\mathrm{i}}{ }^{1} \cdot \mathrm{s}_{\mathrm{i}}{ }^{2} \cdot \mathrm{W}_{\mathrm{i}}{ }^{2} \cdot \mathrm{C}_{\mathrm{i}}^{\text {SparkIc. }} \\
& Y_{i}=f\left(E_{i}{ }^{1}, E_{i}{ }^{11}, E_{i}{ }^{12}, E_{i}{ }^{2}, Z_{i}, M_{i}, B_{i}, B_{i}{ }^{11}, \mathrm{C}_{i}{ }_{i}{ }^{\text {Sparklc }}, B_{i}{ }^{2}, X_{i}, W_{i}, W_{i}^{11}, W_{i}{ }^{12}, W_{i}{ }^{2}, C_{i}^{\text {str. }}, C_{i}^{\text {drIx }},\right.
\end{aligned}
$$

where $Y_{i}-$ revenue from sales of grape, champagne and sparkling wines;

$\left(\mathrm{E}_{\mathrm{i}}^{1}+\mathrm{E}_{\mathrm{i}}^{2}\right)$ - local consumption:

$\mathrm{E}_{\mathrm{i}}{ }^{1}$ - retail sale of grape wines to the population in the i-region (quantity);

$\mathrm{E}_{\mathrm{i}}^{2}$ - retail sale of champagne and sparkling wines in the i-region (quantity);

$C_{i}^{\text {str. }}$ - price per litre of grape fortified wines with strength up to 20 per cent alcohol;

$\mathrm{C}_{\mathrm{i}}^{\mathrm{drIx}}$ - price per litre of grape table dry, semi-dry, semi-sweet wines with strength of up to 14 per cent of alcohol and up to 8 per cent of sugar;

$\mathrm{C}_{\mathrm{i}}^{\text {SparkIc. }}$ - price per litre of champagne and sparkling wines;

$\mathrm{Z}_{\mathrm{i}}$-investments and expenditures of local government in the i-region;

$\left(\mathrm{M}_{\mathrm{i}}-\mathrm{B}_{\mathrm{i}}\right)$ - from external inputs:

$\mathrm{M}_{\mathrm{i}}$-importation of raw materials for winemaking products into the i-region;

$\mathrm{B}_{\mathrm{i}}$ - importation of winemaking products into the i-region from other regions of the country;

$\mathrm{X}_{\mathrm{i}}$ - exports from the i-region:

$\mathrm{W}_{\mathrm{i}}$ - export of winemaking products to other regions of the country.

\begin{tabular}{|c|c|c|c|c|}
\hline Income type & Dagestan & $\begin{array}{l}\text { Krasnodarskiy } \\
\text { region }\end{array}$ & $\begin{array}{l}\text { Stavropolskiy } \\
\text { region }\end{array}$ & $\begin{array}{l}\text { Rostov- } \\
\text { skiy } \\
\text { region }\end{array}$ \\
\hline \multicolumn{5}{|c|}{ Income that ensures economic base growth } \\
\hline Revenue: & & & & \\
\hline from retail sales $-\mathrm{Vi}$ & 1422.05 & 8082.61 & 2691.34 & 3072.08 \\
\hline - from export $\mathrm{E}_{\mathrm{i}}$ & 2.05 & 45.42 & 2.71 & 31.06 \\
\hline regions $-\mathrm{W}_{\mathrm{i}}$ & 1530.08 & 1362.79 & 966.9 & 1205.36 \\
\hline Total revenue & 2954.18 & 9490.82 & 3660.95 & 4308.5 \\
\hline $\begin{array}{l}\text { Investment } * \\
\text { in viticulture and } \\
\text { winemaking }-\mathrm{I}_{\mathrm{i}}\end{array}$ & 24.6 & 36.25 & 7.82 & 6.13 \\
\hline Total & 2978.78 & 9527.07 & 3668.77 & 4314.63 \\
\hline \multicolumn{5}{|c|}{ Factors that reduce the economic base } \\
\hline $\begin{array}{l}\text { Import- } \mathrm{M}_{\mathrm{i}} \\
\text { Import from other } \\
\text { regions }-\mathrm{B}_{\mathrm{i}}\end{array}$ & -205.18 & $\begin{array}{l}-123.14 \\
-247.32\end{array}$ & $\begin{array}{r}-96.0 \\
-13.54\end{array}$ & $\begin{array}{l}-435.9 \\
-128.1\end{array}$ \\
\hline
\end{tabular}

Calculations based on the original data of the regions of the South of Russia are presented in table 1.

Table 1. Economic base of the wine market in the main wine-producing regions of the SFO, million. rub., per year. 


\begin{tabular}{|l|c|c|c|c|}
\hline Total & -205.18 & -370.46 & -109.50 & -564.0 \\
\hline $\begin{array}{l}\text { The economic base of } \\
\text { winemaking }\end{array}$ & 2773.6 & 9156.61 & 3559.27 & 3750.63 \\
\hline
\end{tabular}

*Only foreign Russian state investments have been taken into account.

The findings of G. Moody and F. Pafer [1] and others also show that the ratio of basic to tertiary sectors is not constant. Moreover, this indicator does not take into account the effects of feedback on economic development. As D. Thompson [1] points out, growth tends to lead to further growth and concomitant increases in demand for locally produced products. This group of enterprises may in fact export part of the product, but its original purpose is to meet domestic needs.

Delay is also a problem. The relationship between basic and tertiary sectors may not be in a state of equilibrium, but rather reflect, with some delay, past changes in the factors affecting the region. [13-21]

The division of multipliers is possible with the questionnaire method of sectoral delimitation: the researcher can extract the «Keynesian» multiplier by precisely establishing the relationships between activities. This separation cannot be made using the specialization factor or the minimum requirement method.

\section{Consolation}

Some generalizations can be made from the analysis of methods. Both the facts that analysis of the economic base is an accelerated method of analysing and forecasting regional economic growth and does not require much information and that the growth model is well suited to assessing the economic base of any industry, including the wine market, should be considered as positive outcomes. Among negative outcomes comes the fact that the results are limited to forecasting the development of the basic and the tertiary sectors. The accuracy of forecasting is reduced due to a number of technical and conceptual problems, such as the stability of the relationship between the basic and tertiary sectors and the incorrect division of sectors.

\section{References}

1. K. Anderson, S. Nelgen, Wine's Globalization: New Opportunities, New Challenges. Working Paper No. 0111 (Wine Economics Research Centre, University of Adelaide, 2011)

2. G. Wittwer, N. Berger, K. Anderson, Economic Modelling 20, 487-506 (2011)

3. D. Vergamini, F. Bartolini, P. Prosperi, G. Brunori, Explaining regional dynamics of marketing strategies: The experience of the Tuscan wine producers 72, 136-152 (2019)

4. A. Hira, T. Swartz, Wine Economics and Policy 3, 37-53 (2014)

5. T. Battaglene, Proceedings of the APEC Wine Trade and Regulatory Conference, Seminar on Key Issues in Wine Regulation (San Francisco, California, 2011)

6. K. Anderson, Economic Papers 29(2), 215-228 (2011)

7. K. Anderson, S. Nelgen, Global Wine Markets, 1961-2009: A Statistical Compendium (The University of Adelaide Press, Adelaide, 2011)

8. G. Banks, J. Overton, Journal of Wine Research 21(1), 57-75 (2014)

9. T. Battaglene, Proceedings of the Importance of International Organizations in Wine Regulation, Seminar on Key Issues in Wine Regulation (San Francisco, California, 2015) 
10. I. Chaney, International Journal of Wine Marketing 14(1), 34-42 (2016)

11. A. Deardorff, R. Stern, Measurement of Non-Tariff Barriers. Working Papers No. 179 (OECD Economics Department, 2014)

12. M. Hussain, S. Cholette, R. Castaldi, Journal of Global Marketing 21(1), 33-47 (2016)

13. P. Mora, International Journal of Wine Marketing 18(2), 139-149 (2018)

14. H. Remaud, J.-P. Couderc, Agribusiness 22(3), 405-416 (2017)

15. C. Santini, A. Cavicchi, B. Rocchi, International Journal of Wine Business Research 19(3), 216-230 (2015)

16. J.-P. Couderc, G. Giordano, H. Remaud, Les enterprises de la filière vin (La documentation Française, Paris, 2010)

17. E. Giuliani, A. Morrison, R. Rabellotti, Innovation and Technological Catch-Up The Changing Geography of Wine Production (Cheltenham United Kingdom, 2011)

18. European Commission, Report from the Commission to the European Parliament and the Council in accordance with Article 184(7) of Council Regulation (EC) No. 1234/2007 on implementation of the measure for the promotion of wines on thirdcountry markets (SEC(2011) 1371 final) (Brussels, 2011)

19. A. Mariani, F. Napoletano, E. Pomarici, Le Bulletin de l'OIV 84 (2011)

20. International Trade Barriers Report for U. Wines (Wine Institute, 2010)

21. Wine Intelligence, 2012. Opportunities for sparkling wine in emerging markets, short note, http.//www.wineintelligence.com 